\title{
Analisis Karaterisasi Konsentrasi dan Komposisi Partikulat Udara (Studi Case : Surabaya)
}

\author{
Eka Fitriani Ahmad ${ }^{1}$, Muhayatun Santoso ${ }^{2}$ \\ ${ }^{1}$ Prodi kimia, Fakultas Sains dan Teknologi, UIN Syarif Hidayatullah, Jl. Ir. H Juanda No.95 Ciputat 15412 \\ ${ }^{2}$ PSTNT BATAN Jl. Taman Sari No. 71 Bandung 40132 \\ Email: eka.fithriani@gmail.com
}

Received: September 2016; Revised: October 2016; Accepted: November 2016; Available Online: December 2016

\begin{abstract}
Abstrak
Pencemaran udara merupakan dampak yang sangat merugikan, tidak hanya bagi manusia tetapi juga akan berdampak buruk bagi ekosistem hewan dan tumbuhan. Pada penelitian ini akan mengkaji pencemaran udara dari Oktober 2012 hingga Februari 2014 melalui penelitian konsentrasi dan komposisi dari partikulat udara dengan ukuran PM 2.5. Penelitian ini bertujuan untuk menentuan sumber asal pencemaran di Surabaya sehingga dapat dijadikan referensi berbasis ilmiah sebagai langkah untuk membuat keputusan dan kebijakan yang tepat dalam menanggulangi dampak pencemaran. Metode pengolahan data dalam penelitian ini adalah dengan menggunakan analisis reseptor modeling yaitu Positif Matrix Factorization (PMF) untuk mengetahui sumber asal pencemaran. Hasil pengukuran yang diperoleh pada konsentrasi PM 2,5 adalah $15.05 \mu \mathrm{g} / \mathrm{m}^{3}$ sehingga telah melebihi baku mutu tahunan yang telah ditetapkan PP 41 tahun 1999, USEPA, maupun WHO. Dalam partikulat terdapat konsentrasi black carbon (BC) sebesar $3.20 \mu \mathrm{g} / \mathrm{m}^{3}$ dan unsur $\mathrm{Pb}$ dengan konsentrasi $0.28 \mu \mathrm{g} / \mathrm{m}^{3}$ yang telah melebihi nilai baku mutu USEPA. Sedangkan hasil analisis reseptor modeling di dapatkan sumber asal polutan berasal dari biomass, vehicle, soil, industri $\mathrm{Pb}$, industri $\mathrm{Zn}$ dan indutri $\mathrm{Fe}$.
\end{abstract}

Kata kunci: Partikulat mater 2.5, black carbon, Pb, positive matrix factorization, Surabaya

\begin{abstract}
Air pollution is a very adverse impact, not only for humans but also the ecosystem of plants and animals. This research examine air pollution from October 2012 until February 2014 through the research of concentration and composition of airborne particulates with a size of PM $2.5 \mu \mathrm{m}$. This study aims to determine the origin and location of pollution sources in Surabaya so that it can be used as scientific reference as a step to make the right decisions and policies in tackling the impact of pollution. Data processing method in this research used analysis of receptor modeling that is Positive Matrix Factorization (PMF) to determine the source of the pollution. Results obtained at a concentration of PM 2.5 was $15.05 \mu \mathrm{g} / \mathrm{m}^{3}$ so PM 2.5 has exceeded the quality standard yearly, based on PP 41 1999, USEPA and WHO. There are $3.20 \mu \mathrm{g} / \mathrm{m}^{3}$ concentration of black carbon (BC), element of lead $(\mathrm{Pb})$ in particulate matter with a concentration $0.28 \mu \mathrm{g} / \mathrm{m}^{3}$ which has exceeded the value of the quality standard of USEPA. The sources of pollutants come from biomass, vehicle, soil, industrial $\mathrm{Pb}, \mathrm{Zn}$ and industries Fe industry.
\end{abstract}

Keywords: Particulate matter 2.5, black carbon, Pb, positive matrix factorization, Surabaya

DOI: $h t t p: / / d x . d o i . o r g / 10.15408 / j k v \cdot v 0 i 0.3602$

\section{PENDAhuluan}

Pencemaran udara didefinisikan sebagai masuknya suatu komponen lain kedalam udara ambient dengan jumlah tertentu sehingga kualitas udara menurun yang akan berdampak membahayakan bagi kesehatan manusia dan ekosistem alam (Cooper et al, 1994). Studi epidemologi menunjukkan adanya hubungan yang signifikan antara mortality dengan konsentrasi particulate matter (PM) khususnya fine particulate yang secara efisien 
dapat menembus ke dalam paru-paru sehingga meningkatkan insiden resiko penyakit pernafasan dan kardiovaskular (Breu et al., 2013). Pencemaran udara perlu dilakukan upaya managemen polusi sehingga dapat menurunkan atau meminimalisir terhadap dampak yang akan ditimbulkan. Namun, salah satu kesulitan utama dalam melakukan manajemen polusi udara adalah menentukan hubungan kuantitatif antara kualitas udara ambien dengan sumber pencemar. Sehingga, satu-satunya metode yang dapat diterapkan untuk mereduksi konsentrasi polutan adalah dengan mengidentifikasi sumber yang mengemisikan polutan tersebut.

Source apportionment adalah proses identifikasi dari sumber asal emisi aerosol dan konstribusi massa emisi tersebut. Di indonesia, reseptor modeling dengan menggunakan positif matriks factorization (PMF) telah dilakukan oleh Santoso (2008, 2011, dan 2013) untuk mengidentifikasi sumber pencemar di wilayah Bandung, Lembang dan Serpong. Positif matriks factorization (PMF) merupakan teknik yang dikembangkan oleh oleh Paatero dan Tapper untuk memberikan pendekatan pemodelan yang fleksibel yang dapat mendeskripsikan informasi dalam data (Paatero dan Taaper,1997). Pemodelan ini merupakan metode untuk menentukan trace element dari komponen terpenting dalam aerosol seperti fingger print yang berasal dari industri, emisi rumah tangga, dan emisi kendaraan bermotor atau aktifitas lainnya yang menghasilkan polusi sehingga meningkatkan pencemaran di udara (Gugamsetty et al., 2012).

Surabaya merupakan salah satu kota kedua terbesar kepadatan penduduk setelah jakarta di Indonesia. Menurut Chamida (2004) jumlah konsentrasi particulat matter (PM) 10 $\mu \mathrm{m}$ rerata harian pada tahun 2001 sebesar 150 $\mu \mathrm{g} / \mathrm{m}^{3}$, pada tahun 2002 sebesar $240 \mu \mathrm{g} / \mathrm{m}^{3}$, dan pada tahun 2003 sebesar $170 \mu \mathrm{g} / \mathrm{m}^{3}$ sehingga dapat diidentifikasikan bahwa kualitas udara di Surabaya telah melebihi ambang batas yang telah ditetapkan. Sedangkan berdasarkan hasil laporan kegiatan 2013 antara BATAN dengan BLH (Santoso et al, 2013), rerata harian konsentrasi particulate matter 2.5 tahun 2012-2013 di Surabaya sudah melebihi ambang batas yang telah ditetapkan yaitu sebesar $15.8 \mu \mathrm{g} / \mathrm{m}^{3}$.

Merujuk pada hasil-hasil penelitian tersebut, Surabaya perlu melakukan managemen pecemaran menggunakan reseptor modeling dengan tujuan untuk mengatasi pencemaran udara yang akan menyebabkan udara tidak dapat berfungsi sebagaimana mestinya serta dapat mempengaruhi kesehatan makhluk hidup.

\section{METODE PENELITIAN}

Metode pengambilan sampel menggunakan sistem Gent Sampler yang berada di atap gedung tersebut selama 24 jam dengan laju alir $\pm 18 \mathrm{~L} / \mathrm{min}$. Prinsip kerja dari penggunaan Gent Sampler adalah untuk mengumpulkan sampel partikulat udara. Material filter yang digunakan berjenis polycarbonate dengan diameter $47 \mathrm{~mm}$, dengan ukuran pori $4 \mu \mathrm{m}$. Analisis pengukuran partikulat menggunakan metode gravimetri untuk menentukan berat massa dari sampel PM dengan mengukur selisih berat massa dari berat jenis sebelum dan sesudah dilakukan proses sampling, dimana kondisi ruangan diatur pada suhu $18-23{ }^{\circ} \mathrm{C}$ dan humidity $45-55$ $\mathrm{g} / \mathrm{m}^{3}$. Hal ini dilakukan supaya kadar air dalam debu tersebut stabil. Pengukuran BC dilakukan menggunakan alat EEL 43D Smoke Stain Reflactometer. Analisis kandungan logam pada penelitian ini menggunakan EDXRF 3D Epsilon 5. Keuntungan penggunaan metode EDXRF adalah multiunsur, non destruktif, memiliki sensitivitas dan selektivitas yang tinggi. Sedangkan untuk penentuan sumber pencemar menggunakan positif matriks factorization (PMF).

\section{HASIL DAN PEMBAHASAN}

Pada penelitian ini pengambilan sampel partikulat udara berlokasi di UPT Laboratorium Uji Kualitas Lingkungan Badan Lingkungan Hidup Provinsi Jawa Timur yang beralamat di Jl. Wisata Menanggal No. 38 Surabaya dimana proses pengambilan data yaitu diawali pada Oktober 2012 hingga Februari 2014. Konsentrasi PM 2,5 diperoleh dari filter fine partikel sedangkan untuk konsentrasi PM 10 diperoleh dengan menjumlahkan filter fine dan filter coarse. Konsentrasi maka membandingkan dengan standar untuk menentukan apakah konsentrasi dari PM udara ambient di Surabaya telah melebihi ambang batas. Hasil pengukuran PM 2,5 berdasarkan time series di Surabaya ditunjukkan pada Gambar 1. Sedangkan, hasil 
pengukuran PM 10 berdasarkan time series di Surabaya ditunjukkan pada Gambar 2.

Gambar 2 menunjukkan bahwa fluktuatif tinggi rendahnya konsentrasi pada PM 2.5 dan PM 10 sangat dipengaruhi oleh musim. Pada awal tahun 2013 diawali dengan musim hujan, sehingga konsentrasi partikulat di udara menjadi rendah karena partikulat di udara akan tertangkap oleh butiran-butiran air hujan. Musim kemarau 2013 diawali dibulan Juli namun masih dalam kategori kemarau bulan basah dengan curah hujan lebih besar dari 100 tetapi kurang $150 \mathrm{~mm}$ perbulan sehingga masih terjadi hujan dengan intensitas bervariasi. Musim kemarau dengan intensitas curah hujan 0 di mulai pada bulan Agustus sehingga menyebabkan konsentrasi sangat tinggi pada bulan ini. Hal ini sesuai dengan data pattern partikulat yang didapat berdasarkan tanggal sampling, konsentrasi tinggi di bulan Juli dan Agustus dikarenakan telah memasuki musim kemarau. Adanya hubungan antara musim dengan besaran konsentrasi, dimana semakin tinggi penguapan semakin besar konsentrasi yang didapatkan karena tidak adanya butiran-butiran air yang terperangkap dalam partikulat. Secara umum, ringkasan hasil pengukuran konsentrasi PM 2.5 dan PM 10 pada sampel partikulat udara di Surabaya ditunjukkan pada Tabel 1.

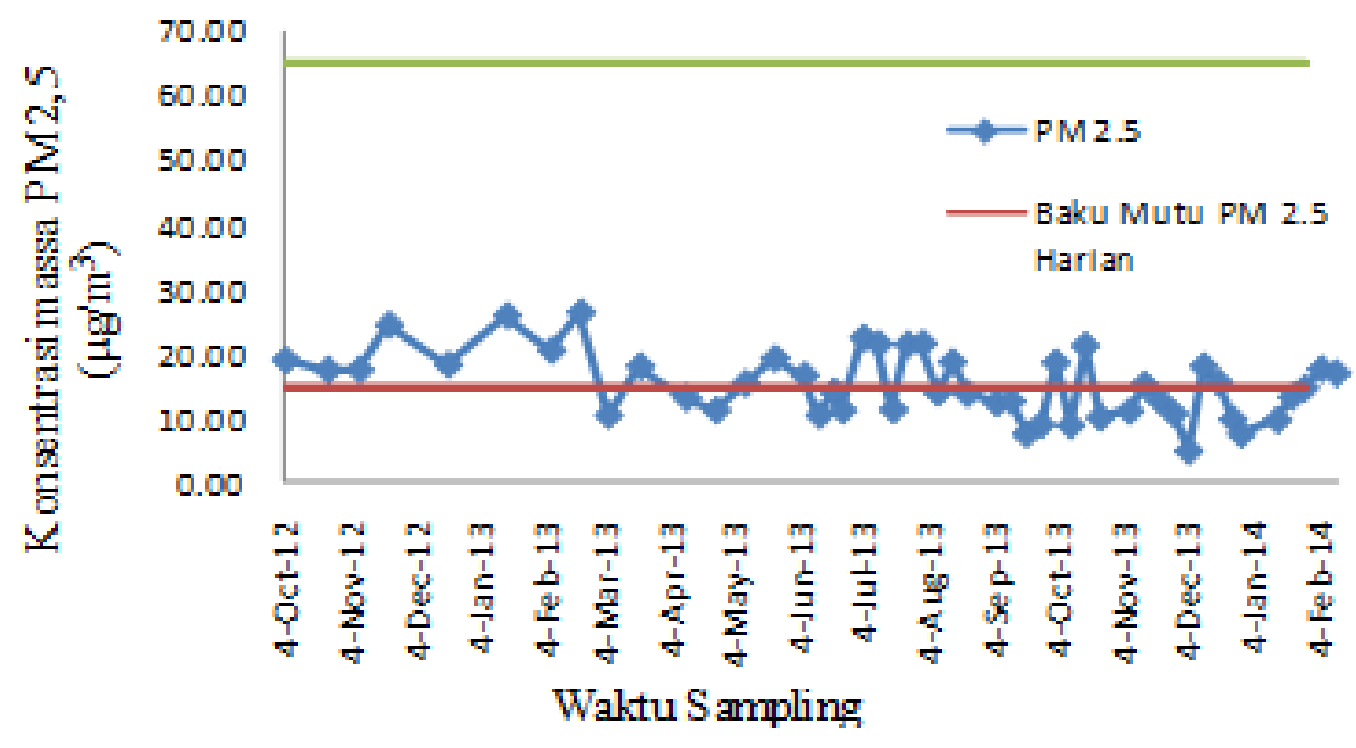

Gambar 1. Konsentrasi massa PM 2.5 di Surabaya

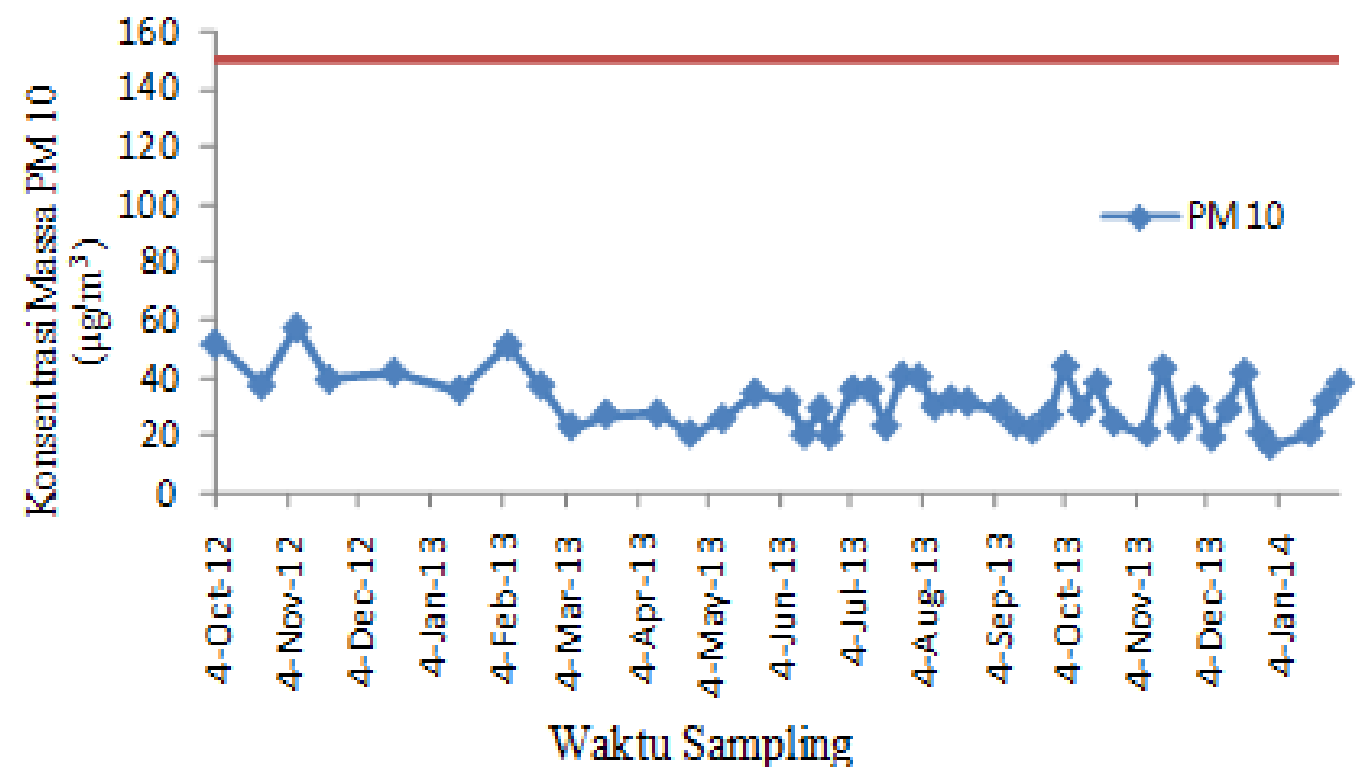

Gambar 2. Konsentrasi massa PM 10 di Surabaya 
Tabel 1. Konsentrasi PM 2.5 dan PM 10 (rerata tahunan) di Surabaya

\begin{tabular}{cccc}
\hline Parameter & $\begin{array}{c}\text { Rerata } \\
\left(\mu \mathrm{g} / \mathrm{m}^{3}\right)\end{array}$ & $\begin{array}{c}\text { Rentang } \\
\left(\mu \mathrm{g} / \mathrm{m}^{3}\right)\end{array}$ & $\begin{array}{c}\text { Standar } \\
\text { Deviasi } \\
\left(\mu \mathrm{g} / \mathrm{m}^{3}\right)\end{array}$ \\
\hline PM 2,5 & 15.05 & $8.53-26.38$ & 4.77 \\
PM 10 & 30.41 & $18.35-50.65$ & 9.37 \\
\hline
\end{tabular}

Berdasarkan PP 41 tahun 1999 tentang baku mutu udara ambien pada partikulat matter, PM 2.5 di Surabaya pada Oktober 2012 hingga Februari 2014 telah melebihi baku mutu tahunan yaitu $15.05 \mu \mathrm{g} / \mathrm{m}^{3}$ sedangkan baku mutu yang telah di standarkan sebesar 15 $\mu \mathrm{g} / \mathrm{m}^{3}$. Selisih nilai tersebut merupakan hasil yang didapat dengan total data sebanyak 80 . Sehingga dapat disimpulkan bahwa setiap hari pencemaran udara di surabaya telah melebihi standar baku mutu. Selain itu, PM 2.5 di Surabaya pada Oktober 2012 hingga Februari 2014 juga telah melebihi rerata tahunan dari standar yang telah ditetapkan WHO yaitu 10 $\mu \mathrm{g} / \mathrm{m}^{3}$ dan USEPA yaitu $15 \mu \mathrm{g} / \mathrm{m}^{3}$. Pada PM 10 di Surabaya pada Oktober 2012 hingga Februari 2014 belum melebihi ambang batas yang telah ditentukan PP 41 tahun 1999 yaitu $150 \mu \mathrm{g} / \mathrm{m}^{3}$, US EPA $150 \mu \mathrm{g} / \mathrm{m}^{3}$ dan WHO 50 $\mu \mathrm{g} / \mathrm{m}^{3}$.

Selain itu, Apabila melihat Rasio antara PM 2.5 dan PM 10 memberikan nilai rerata sebesar 0.49 yang menunjukkan bahwa PM 2,5 memberikan konstribusi 0.49 dari total massa PM 10 serta mengidentifikasikan bahwa pencemaran dari sumber atropogenik mencapai 49\%. Tingginya konstribusi konsentrasi PM 2.5 disebabkan oleh oleh peningkatan jumlah kendaraan bermotor, maupun konsumsi bahan bakar fosil untuk kegiatan perindustrian. Rasio antara PM 2,5 dan PM 10 ditunjukkan oleh Gambar 3.

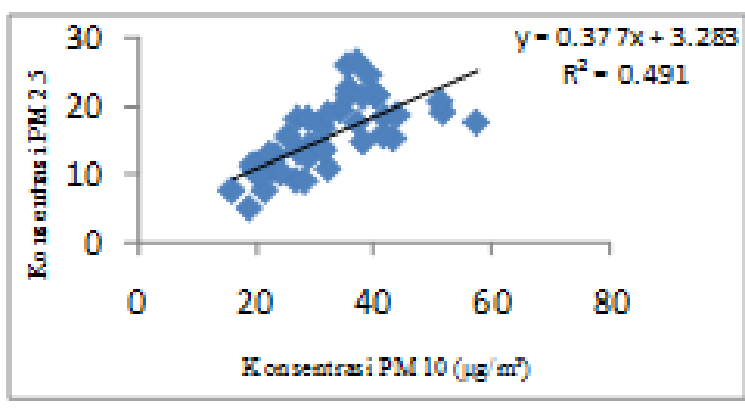

Gambar 3. Korelasi PM 2.5 dan PM 10 di Surabaya
Selain konsentrasi, kajian perhitungan komposisi dalam konsentrasi patikulat dapat ditentukan dengan menggunakan teknik constructed mass (RCM). RCM merupakan suatu metoda penjumlahan dari konsentrasi berbagai macam faktor yang berdistribusi pada konsentrasi PM. Lima faktor utama yang terdapat pada komposisi pembentuk partikulat diantaranya black carbon (BC), material organik (MO), sulfat, garam laut (seasalt), debu tanah (soil), dan asap (smoke). Perhitungan dari penjumlahan RCM adalah sebagai berikut:

$$
\mathrm{RCM}=\text { Sulfat }+ \text { Seasalt }+ \text { Smoke }+ \text { Soil }+\mathrm{BC}+\mathrm{MO}
$$

Setiap faktor merupakan hasil jumlah konsentrasi massa unsur-unsur penanda, seperti :

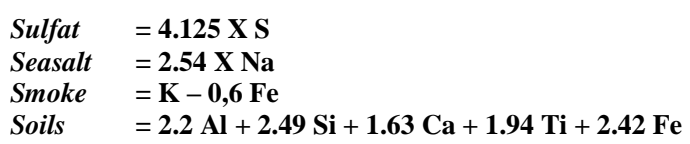

Berdasarkan perhitungan diatas, maka konsentrasi massa RCM pada partikulat matter PM 2.5 dan PM 10 di deskripsikan pada Tabel 2.

Tabel 2. Perbandingan komposisi fine partikulat dan coarse partikulat

\begin{tabular}{lcc}
\hline \multirow{2}{*}{ Faktor } & \multicolumn{2}{c}{ PM 2.5 } \\
\cline { 2 - 4 } & $\begin{array}{l}\text { Konsentrasi } \\
\left(\mu \mathrm{g} / \mathrm{m}^{3}\right)\end{array}$ & $\begin{array}{l}\text { Faktor/PM 2.5 } \\
(\%)\end{array}$ \\
\hline BC & 3.20 & 20.95 \\
Sulfur & 2.19 & 14.36 \\
Sea salt & 0.71 & 4.67 \\
Smoke & 0.20 & 1.33 \\
Soil & 1.70 & 11.13 \\
RCM & & 8.01 \\
PM & & 15.27 \\
RCM/PM & & 52.44 \\
\hline
\end{tabular}

Pada Tabel 2 terlihat perbandingan komposisi pada RCM PM 2.5 partikulat maka dapat dianalisa bahwa komposisi PM 2.5 didominasi oleh $\mathrm{BC}$ yang umumnya berasal dari kegiatan antropogenik. Konsentrasi massa total RCM pada Oktober 2012 hingga Februari 2014 adalah $8.01 \mu \mathrm{g} / \mathrm{m}^{3}$ pada PM 2.5. Rasio komposisi RCM terhadap pengukuran konsentrasi massa particulat untuk fine partikel sebesar $52.44 \%$ dan untuk coarse particulat sebesar $45.31 \%$ sisa dari prosentasi masing masing particulate merupakan 
konsentrasi dari organik carbon serta aerosol sekunder ammonium nitrat.

Pengukuran BC dilakukan karena BC merupakan komponen utama dari partikulat metter yang bersifat toksis sehingga ditetapkan sebagai regulated pollutant. Selain itu, BC merupakan unsur ke dua penyebab global warning yang diakibatkan oleh pembakaran yang tidak sempurna. Hasil pengukuran BC dengan reflektansi menggunakan alat EEL 43D Smoke Stain Reflactometer terdeskripsikan pada Tabel 3.

Tabel 3. Parameter BC

\begin{tabular}{ccccc}
\hline Parameter & $\begin{array}{c}\text { Rerata } \\
\left(\mu \mathrm{g} / \mathrm{m}^{3}\right)\end{array}$ & $\begin{array}{c}\text { Rentang } \\
\left(\mu \mathrm{g} / \mathrm{m}^{3}\right)\end{array}$ & $\begin{array}{c}\text { Standar } \\
\text { Deviasi } \\
\left(\mu \mathrm{g} / \mathrm{m}^{3}\right)\end{array}$ & $\begin{array}{c}\text { Rasio } \\
\mathrm{BC} / \mathrm{PM}\end{array}$ \\
\hline BC (PM 2.5) & 3.20 & $1.56-5.69$ & 0.84 & 22 \\
BC (PM 2.5 & 0.71 & $0.31-1.30$ & 0.23 & 5 \\
- PM 10) & & & & \\
\hline
\end{tabular}

Berdasarkan Tabel 3 selama periode Oktober 2012 - Februari 2014, konsentrasi BC pada PM 2.5 di Surabaya berada di rentang konsentrasi $1.56-5.69 \mu \mathrm{g} / \mathrm{m}^{3}$ dengan rerata konsentrasi $3.20 \mu \mathrm{g} / \mathrm{m}^{3}$ sedangkan $\mathrm{BC}$ pada
PM 2.5-10 berada di rentang konsentrasi 0.31$1.30 \mu \mathrm{g} / \mathrm{m}^{3}$ dengan rerata konsentrasi $0.71 \mu \mathrm{g} / \mathrm{m}^{3}$. Konsentrasi BC pada PM 2.5 lebih besar konsentrasinya bila dibandingkan dengan BC pada PM 2.5-10. Hal ini dikarenakan, BC merupakan jelaga hitam yang dihasilkan dari proses pembakaran yang tidak sempurna sehingga sebagian besar berasal dari sumber antropogenik seperti biomass dan aktivitas di jalan raya yang umumnya terabsorb kedalam PM 2.5. Pernyataan ini sejalan dengan penelitian yang dilakukan Mukhtar et al (2013) yang menyatakan bahwa konsentrasi $\mathrm{BC}$ pada PM 2.5 lebih tinggi daripada konsentrasi BC pada PM 2.5-10. Konstribusi BC dalam konsentrasi PM 2.5 dan PM 2.5-10 adalah $22 \%$ untuk PM 2.5 dan 5\% untuk PM 2.5-10.

Selain BC, faktor-faktor lain yang terdapat pada partikulat matter merupakan finger print dari berbagai logam pembentuknya. Untuk wilayah Surabaya pada periode Oktober 2012-Februari 2014, particulate mengandung logam-logam seperti yang di deskripsikan pada Tabel 4 sebagai berikut.

Tabel 4. Logam-logam yang terkadung pada PM 2.5 dan PM 2.5-10.

\begin{tabular}{|c|c|c|c|c|c|c|c|c|}
\hline \multirow[t]{2}{*}{ Unsur } & \multicolumn{4}{|c|}{ PM $2.5\left(\mathrm{ng} / \mathrm{m}^{3}\right)$} & \multicolumn{4}{|c|}{ PM $2.5-10\left(\mathrm{ng} / \mathrm{m}^{3}\right)$} \\
\hline & Min & Max & Mean & St. Dev & Min & Max & Mean & St. Dev \\
\hline $\mathrm{Na}$ & 21.87 & 597.45 & 280.57 & 119.95 & 29.07 & 585.71 & 250.79 & 137.44 \\
\hline $\mathrm{Al}$ & 137.23 & 514.74 & 185.14 & 54.76 & 213.96 & 886.51 & 437.28 & 150.66 \\
\hline $\mathrm{Si}$ & 55.64 & 1245.08 & 167.29 & 165.13 & 241.35 & 1827.99 & 772.89 & 337.39 \\
\hline $\mathrm{S}$ & 5.67 & 955.31 & 531.33 & 176.17 & 1.90 & 665.02 & 189.23 & 127.53 \\
\hline K & 11.14 & 442.78 & 203.50 & 87.81 & 46.42 & 323.94 & 130.18 & 60.35 \\
\hline $\mathrm{Ca}$ & 27.64 & 267.85 & 85.36 & 38.88 & 199.75 & 1438.41 & 507.49 & 240.06 \\
\hline $\mathrm{Ti}$ & 3.91 & 23.10 & 9.12 & 3.00 & 12.40 & 82.04 & 32.13 & 14.16 \\
\hline Mn & 3.38 & 30.42 & 13.05 & 6.04 & 6.20 & 43.84 & 18.26 & 8.74 \\
\hline $\mathrm{Fe}$ & 212.04 & 475.16 & 320.74 & 63.23 & 304.05 & 1174.97 & 609.72 & 181.60 \\
\hline $\mathrm{Cu}$ & 15.16 & 991.76 & 317.33 & 204.99 & 15.98 & 803.06 & 270.80 & 178.17 \\
\hline $\mathrm{Zn}$ & 8.11 & 1910.85 & 324.64 & 400.83 & 2.09 & 835.42 & 118.66 & 159.83 \\
\hline $\mathrm{Pb}$ & 21.87 & 597.45 & 280.57 & 119.95 & 29.07 & 585.71 & 250.79 & 137.44 \\
\hline
\end{tabular}


Pengukuran komposisi unsur logam adalah faktor utama dalam penggunaan data untuk menentukan kemungkinan sumber pencemar, dimana proses identifikasi dan pengelompokkan polutan ke sumbernya adalah langkah yang sangat penting dalam memanagement kualitas udara. Berdasarkan tabel 4 unsur-unsur logam yang terkandung pada PM 2.5 maupun PM 2.5-10 terdapat 12 unsur logam diantaranya $\mathrm{Na}, \mathrm{Al}, \mathrm{Si}, \mathrm{S}, \mathrm{K}, \mathrm{Ca}$, $\mathrm{Ti}, \mathrm{Mn}, \mathrm{Fe}, \mathrm{Cu}, \mathrm{Zn}$ dan $\mathrm{Pb}$. Dari 12 unsur logam tersebut unsur logam $\mathrm{Pb}$ menjadi fokus penelitian ini karena konsentrasi logam $\mathrm{Pb}$ merupakan logam yang bersifat toksik. Selain itu, berdasarkan National ambient air Quality Standards (NAAQS) terdapat enam kajian parameter kualitas udara diantaranya $\mathrm{Pb}$. Standar konsentrasi $\mathrm{Pb}$ berdasarkan NAAQS sebesar $0.15 \mu \mathrm{g} / \mathrm{m}^{3}$ sedangkan konsentrasi $\mathrm{Pb}$ di Surabaya untuk PM 2.5 sebesar $0.28 \mu \mathrm{g} / \mathrm{m}^{3}$ dan untuk PM 2.5-10 sebesar $0.27 \mu \mathrm{g} / \mathrm{m}^{3}$. Sehingga kualitas $\mathrm{Pb}$ dalam partikulat udara di Surabaya pada Oktober 2012-Februari 2014 telah melebihi baku mutu National ambient air Quality Standards (NAAQS) dari USEPA. Namun bila dibandingkan dengan standar baku mutu PP 41 tahun 1999 untuk $\mathrm{Pb}$ sebesar 2 $\mu \mathrm{g} / \mathrm{m}^{3}$ (24 jam) atau $1 \mu \mathrm{g} / \mathrm{m}^{3}$ (1 hari) maka kualitas $\mathrm{Pb}$ dalam partikulat udara di Surabaya pada Oktober 2012 hingga Februari 2014 belum melebihi baku mutu yang telah ditetapkan. Sehingga dapat ditarik kesimpulan bahwa konsentrasi $\mathrm{Pb}$ dalam PM 2.5 maupun PM 2,5-10 telah melebihi baku mutu NAAQS dari USEPA akan tetepi belum melebihi baku mutu PP 41 tahun 1999.

Pengukuran komposisi unsur logam adalah faktor utama dalam penggunaan data untuk menentukan kemungkinan sumber pencemar. Sumber penghasil particulate dapat diperkirakan dengan cara mengetahui unsurunsur logam yang terkandung dalam particulate tersebut serta dapat memperlihatkan hubungan korelasi antara usur logam dengan unsur logam lainnya. Pada penelitian ini menggunakan metode Positif Matrix Factorization (PMF) yang dapat digunakan untuk penentuan sumber pencemar sehingga merupakan upaya preventif untuk mengurangi pencemaran. PM 2.5 merupakan pencemaran yang bersumber pada kegiatan antropogenik sehingga metode Positif Matrix Factorization (PMF) sangat baik untuk dilakukan. Berdasarkan hasil analisis Positif Matrix Factorization (PMF), sumber pencemar di Surabaya pada Oktober 2013 hingga Februari 2014 terdiri dari 6 faktor sumber pencemar yang di ilustrasikan pada Gambar 4 .

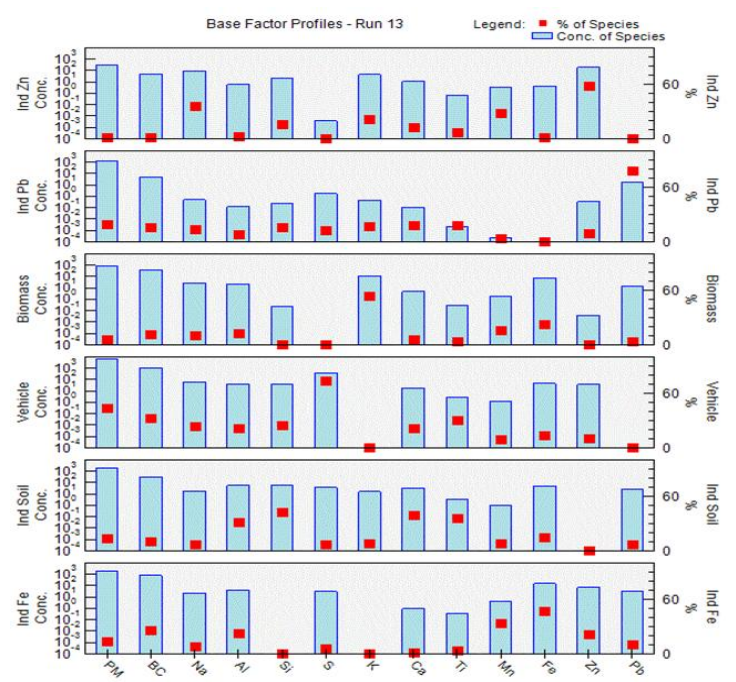

(a)

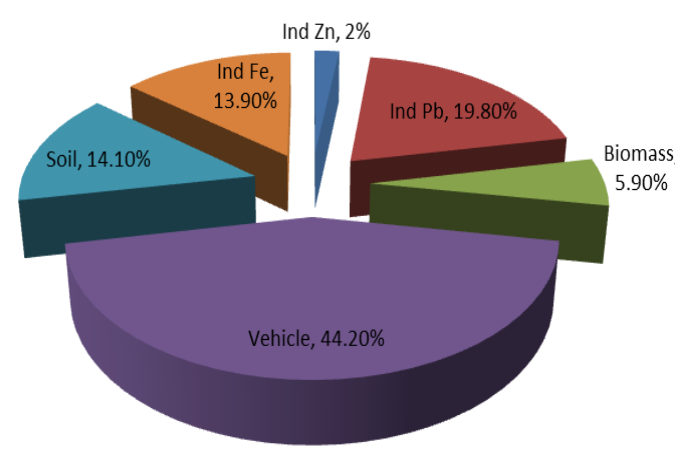

(b)

Gambar 4. Profile sumber pencemar (a), konstribusi sumber pencemar pada PM 2.5 (b)

Faktor Pertama dimungkinkan merupakan indikasi dari industri metal nonferrous dengan sea salt karena konsentrasi terbesar pada faktor ini adalah konsentrasi $\mathrm{Zn}$ dan konsentrasi $\mathrm{Na}$. Konstribusi faktor ini adalah sebesar $2 \%$ terdapat dalam PM 2.5. Faktor kedua merupakan indikasi dari peleburan $\mathrm{Pb}$ dikarenakan konsentrasi terbesar adalah konsentrasi $\mathrm{Pb}$. Untuk konstribusi $\mathrm{Pb}$ pada PM 2.5 yaitu sebesar 19.8\%. Faktor ketiga merupakan faktor biomass karena konsentrasi terbesar pada faktor biomass ini adalah $\mathrm{K}$ yang merupakan finger print dari emisi pembakaran biomass. Konstribusi biomass pada PM 2.5 yaitu sebesar $5.9 \%$. Faktor keempat merupakan campuran dari 
vehicle dengan dust road karena konsentrasi dari vehicle ditandai dengan tingginya konsentrasi Sulfur dan BC yang merupakan finger print dari vehicle, sedangkan road dust ditandai dengan tingginya konsentrasi $\mathrm{S}, \mathrm{Ca}$, Ti, Al dan Si. Konstribusi Faktor ke empat ini adalah sebesar $44.2 \%$ dari PM 2.5. konstribusi faktor soil dalam PM 2,5 yaitu sebesar $14.10 \%$. Faktor lima dimungkinkan adalah industri $\mathrm{Fe}$ karena di dominasi oleh konsentrasi Fe, Zn, Mn dan BC. Secara geografis Surabaya diapit oleh kawasan industri seperti Gersik dan Sidoarjo selain Surabaya sendiri memiliki dua kawasan industri seperti Jl. Rungkut Industri Raya, Jl. Brebek Industri dan memiliki kawasan peleburan baja. Konstribusi Industri Fe pada PM 2.5 yaitu sebesar 13.9\%.

\section{SIMPULAN}

Kualitas Udara di Surabaya memiliki konsentrasi PM 2.5 telah melebihi nilai baku mutu tahunan yaitu sebesar $15.05 \mu \mathrm{g} / \mathrm{m}^{3}$ dengan 80 jumlah data, konsentrasi PM 10 sebesar $30.41 \mu \mathrm{g} / \mathrm{m}^{3}$ sehingga tidak melebihi nilai ambang baku dan konsentrasi $\mathrm{Pb}$ telah melebihi nilai baku mutu USEPA yatu sebesar $0.28 \mu \mathrm{g} / \mathrm{m}^{3}$. Sumber asal polutan berasal dari biomass, vehicle, soil, industri $\mathrm{Pb}$, industri $\mathrm{Zn}$ dan indutri $\mathrm{Fe}$

\section{DAFTAR PUSTAKA}

Breu F, Guggenbichler S, Wollmann J. 2013. World health statistics 2013. Geneva : WHO Press.
Chamidha. 2004. Policy for air pollution control strategy by using the air pollutant dispersion model (PM10) in Surabaya. Surabaya: Dinas Lingkungan Hidup Kota Surabaya.

Cooper CD, Alley FC. 1994. Air pollution control a design approach second edition. Illionis: Waveland Press Inc.

Paatero P, U Taaper. 1997. Positive matrix factorization: a non-negative factor model with optimal utization of error estimates of data value. Enviromentric. 5 (5) 111-126.

Santoso M, PK Hopke, A Hidayat, DD Lestiani. 2008. Sources identification of the atmospheric aerosol at urban and suburban sites in indonesia by positive matrix factorization. J. Science of The Total Environment. 397(1-3):229-237.

Santoso M, DD Lestiani, A Markwitz, PK Hopke. 2010. Nuclear analytical techniques INAA and PIXE application for characterization of airborne particulate matter in Indonesia. $J$. of Applied Sciences in Enviromental Sanitation. 5(2): 213-222.

Santoso M, DD Lestiani, A Markwitz, Rita Esrom, Halimah, PK Hopke. 2011. Preliminary study of the source of ambient air pollution in Serpong, Indonesia. J. Air Pollution Research. 2 (2): 190-196.

Santoso M, DD Lestiani, A Markwitz. 2013. Characterization of airborne particulate matter collected at Jakarta roadside of an arterial road. J. of Radioanalytical and Nuclear Chemistry. 297(2): 165-169. 